\title{
Intrauterine growth restriction and hypospadias: is there a connection?
}

\author{
Min-Jye Chen ${ }^{1 *}$, Charles G Macias², Sheila K Gunn', Jennifer E Dietrich ${ }^{3}$, David R Roth ${ }^{4}$, Bruce J Schlomer ${ }^{5}$ \\ and Lefkothea P Karaviti ${ }^{1}$
}

\begin{abstract}
Hypospadias is one of the most common congenital malformations of the genitourinary tract in males. It is an incomplete fusion of urethral folds early in fetal development and may be associated with other malformations of the genital tract. The etiology is poorly understood and may be hormonal, genetic, or environmental, but most often is idiopathic or multifactorial. Among many possible risk factors identified, of particular importance is low birth weight, which is defined in various ways in the literature. No mechanism has been identified for the association of low birth weight and hypospadias, but some authors propose placental insufficiency as a common inciting factor. Currently, there is no standardized approach for evaluating children with hypospadias in the setting of intrauterine growth restriction. We reviewed the available published literature on the association of hypospadias and growth restriction to determine whether it should be considered a separate entity within the category of disorders of sexual differentiation.
\end{abstract}

Keywords: Intrauterine growth restriction, Fetal growth restriction, Small for gestational age, Low birth weight, Placental insufficiency, Hypospadias

\section{Introduction}

Hypospadias is a common congenital malformation in males, occurring in as many as 1 in 125 live male births, with some variation based on ethnicity [1-3]. Defined as an abnormal urethral opening on the ventral surface of the penis, it may be associated with other genitourinary anomalies such as cryptorchidism. Despite some argument to the contrary [3-7], many recent studies have documented an increase in the incidence of hypospadias, both in the United States [8,9] and worldwide [10-13].

Identifying the cause of hypospadias remains a challenge for pediatricians, endocrinologists, and urologists, as the etiology is varied and often idiopathic or multifactorial, particularly for isolated hypospadias. Some cases have a defect in hormonal synthesis, such as in 5-alpha reductase deficiency [14] or androgen insensitivity syndrome [15]. Genetic causes include certain syndromes (e.g., Smith-Lemli-Opitz syndrome [16] and others [17]), abnormalities in sex chromosomes, or mutations in specific genes involved in sexual differentiation [18-20]. Environmental causes also contribute to the development of hypospadias. For example, an increase in the use of pesticides and other endocrine-disrupting chemicals may contribute to the recent increase in incidence [21-25]. Among other maternal-fetal factors, low birth weight (LBW) has been associated with hypospadias, although the mechanism is unclear. Evaluation of this relationship is complicated by inconsistent definitions for LBW or intrauterine growth restriction (IUGR) in the literature. The purpose of this article is to review the association of LBW or IUGR with hypospadias and to determine if hypospadias and IUGR should be considered a distinct entity within disorders of sexual differentiation (DSD) that would require a different process of diagnostic evaluation and treatment.

\section{Methods}

To elucidate the association between IUGR or LBW and hypospadias, we conducted a review of the available 
literature, using PubMed, Cochrane Library, and Google Scholar to answer the following questions:

1. Is growth restriction or LBW associated with hypospadias independently of other related factors, including gestational age?

2. In patients with IUGR and hypospadias, are the diagnostic evaluation and management of the hypospadias different from those for patients without IUGR?

We evaluated studies published in English, including case reports, observational studies, and controlled trials, that describe the relationship between hypospadias and LBW, IUGR, or small for gestational age. Search terms included hypospadias, fetal growth restriction, intrauterine growth restriction, small for gestational age, placental insufficiency, and low birth weight.

\section{Results}

\section{Definitions}

Descriptions of growth restriction vary in the literature, often with definitions based purely on birth weight, size for gestational age, or prenatal measurements. As a result, direct comparisons between studies are difficult. LBW and "small for gestational age (SGA) are both postnatal diagnoses. LBW refers strictly to birth weight [26], whereas SGA may refer to abnormal weight or length for gestational age $[27,28]$. In contrast, IUGR is primarily an obstetric diagnosis, as it depends on prenatal measurements. The term applies when the estimated fetal weight (EFW) is less than expected for gestational age, usually with the restriction persisting over some period of time, though a length of time requirement is not specified in most guidelines [29-31].

There is controversy over the definitions for SGA and IUGR. Though most authors use a cutoff of less than 10th percentile for gestational age for both SGA and IUGR, many researchers propose using more stringent definitions, as most infants who meet the 10th percentile criterion are constitutionally small and have normal perinatal outcomes $[27,32,33]$.

Most studies evaluating the association of growth restriction with hypospadias use SGA or LBW definitions, sometimes interchangeably with IUGR. Although IUGR may lead to the diagnoses of SGA or LBW, the terms are not interchangeable. An infant may be born SGA without having had IUGR, or may have had a short period of IUGR without being SGA. Infants who are SGA may or may not be LBW, depending on gestational age. Pathologic growth restriction may be caused by genetic anomalies such as single gene mutations or chromosomal abnormalities, infections, placental disease, and maternal factors [34]. Studies have linked true fetal growth restriction to multiple congenital anomalies (including, but not limited to, hypospadias) [35-39], increased morbidity in the neonatal period [40], and long-term effects such as neurodevelopmental differences [41], short stature, increased risk of obesity, and metabolic syndrome [42]. Thus, identifying those infants at greatest risk of morbidity calls for a clear definition of IUGR.

\section{Is growth restriction or LBW associated with hypospadias independently of other related factors, including gestational age?}

For decades, epidemiological studies (Table 1) have found that infants with hypospadias have birth weights lower than those of infants without hypospadias [2,35,36,43-46], although the difference in birth weights is not always statistically significant [47]. Because most studies evaluated multiple risk factors, the determination of whether LBW is independently associated with hypospadias or secondary to another risk factor such as maternal age or gestational age remains unknown. More recent population-based studies independently associated birth weight with hypospadias, even after accounting for possible confounders such as prematurity, multiple gestation, and use of assisted reproductive technologies $[4,13,37,48,49]$.

Case control and cohort studies also have found associations between hypospadias and birth weight. Birth weights were lower for boys with hypospadias than for those without hypospadias [50], and hypospadias also was more common in SGA or LBW infants [51]. These studies reported no relationship between gestational age and the frequency of hypospadias.

LBW also is associated with other genital anomalies, including cryptorchidism and more severe forms of DSD. A recent analysis of the International Disorders of Sex Development (I-DSD) registry found that as many as 23 percent of patients with male DSD also had SGA [52]. Patients with more severe anomalies, including hypospadias and undescended testes, have higher rates of IUGR than those with less severe anomalies, such as hypospadias and descended testes [53]. Birth weights and/or lengths are lower in patients with an unknown cause for DSD than in patients with identified causes for DSD, suggesting that growth retardation, particularly early in gestation, may be associated with abnormal testicular differentiation or DSD $[54,55]$.

Twin studies support the relationship between restricted fetal growth and hypospadias by eliminating genetic and external environmental factors. In monozygotic twins discordant for hypospadias, the twin with the lower birth weight more commonly had hypospadias, and the difference in weight was significant $[38,56,57]$. This finding suggests that environmental factors specifically associated with the LBW twin, such as decreased placental blood supply, are involved in the development 
Table 1 Summary of epidemiological studies associating hypospadias with low birth weight

\begin{tabular}{|c|c|c|c|c|c|}
\hline Study (year) & Dataset location (years) & $\begin{array}{l}\text { Number of subjects } \\
\text { with hypospadias }\end{array}$ & Definition & Findings & Other positive associations \\
\hline \multirow[t]{2}{*}{ Chen (1971) [43] } & $\begin{array}{l}\text { Children's Hospital } \\
\text { of Michigan (1961-1967) }\end{array}$ & 50 & NA & $\begin{array}{l}\text { Mean birth weight: hypospadias } \\
2.7 \mathrm{~kg} \text {, expected } 3.3 \mathrm{~kg}\end{array}$ & Parity \\
\hline & & & & $p<0.001$ & \\
\hline \multirow[t]{3}{*}{ Sweet (1974) [2] } & Rochester, Minnesota, USA (1940-1970) & 113 & LBW: $<2500 \mathrm{~g}$ & Presence of LBW in hypospadias 9\% & \\
\hline & & & & Control $2 \%$ & \\
\hline & & & & No $p$ value given & \\
\hline \multirow[t]{2}{*}{ Kallen (1982) [44] } & Sweden (1965-1979) & 1357 & LBW: $<2500 \mathrm{~g}$ & $\begin{array}{c}\text { Presence of LBW in hypospadias } \\
\text { 8.5\%, Expected } 4.2 \%\end{array}$ & Prematurity \\
\hline & & & & $p<0.001$ & \\
\hline \multirow[t]{2}{*}{ Calzolari (1986) [45] } & Emilia Romagna, Italy (1978-1983) & 168 & NA & $\begin{array}{l}\text { Mean birth weight: hypospadias } \\
2.97 \mathrm{~kg} \text {, Controls } 3.39 \mathrm{~kg}\end{array}$ & \multirow{2}{*}{$\begin{array}{l}\text { Mother's age at menarche, } \\
\text { threatened abortion, use of } \\
\text { progestins in pregnancy, } \\
\text { gestational age }\end{array}$} \\
\hline & & & & $p<0.001$ & \\
\hline \multirow[t]{2}{*}{ Kallen (1986) [46] } & Multiple: Denmark, Hungary, Italy, & 7491 & LBW: <2500 g & Presence of hypospadias in LBW: & \multirow{2}{*}{$\begin{array}{c}\text { Maternal age, parity, gestational } \\
\text { age, twin pregnancy }\end{array}$} \\
\hline & $\begin{array}{l}\text { Mexico, South America, Spain, } \\
\text { Sweden (years vary 1967-1982) }\end{array}$ & & & RR 1.8-2.3 (varied by country) & \\
\hline \multirow[t]{2}{*}{ Khoury (1988) [35] } & \multirow[t]{2}{*}{ Atlanta, Georgia, USA (1975-1984) } & \multirow[t]{2}{*}{1111} & \multirow{2}{*}{$\begin{array}{l}\text { IUGR: }<10 \text { percentile birth } \\
\text { weight for gestational age }\end{array}$} & Presence of IUGR in hypospadias: & \multirow[t]{2}{*}{ Not evaluated } \\
\hline & & & & RR (95\% Cl): $2.7(2.3-3.1)$ & \\
\hline \multirow[t]{2}{*}{ Stoll (1990) [47] } & \multirow[t]{2}{*}{ Alsace, France (1979-1987) } & \multirow[t]{2}{*}{176} & \multirow[t]{2}{*}{ NA } & $\begin{array}{c}\text { Mean birth weight: hypospadias } \\
3.19 \mathrm{~kg} \text {, controls } 3.3 \mathrm{~kg}\end{array}$ & \multirow[t]{2}{*}{ Placental weight } \\
\hline & & & & OR 2.05 (95\% Cl 0.73-5.74) & \\
\hline \multirow[t]{5}{*}{ Mili (1991) [36] } & \multirow{5}{*}{$\begin{array}{l}\text { Atlanta, Georgia, } \\
\text { USA (1978-1988) }\end{array}$} & \multirow[t]{5}{*}{919} & \multirow[t]{5}{*}{ NA } & Presence of hypospadias in LBW: & \multirow[t]{7}{*}{ Not evaluated } \\
\hline & & & & Adjusted RR: & \\
\hline & & & & <1500 g: 3.3 & \\
\hline & & & & 1500-1999 g: 3.3 & \\
\hline & & & & $2000-2499$ g: 2.2 & \\
\hline \multirow[t]{2}{*}{ Riley (1998) [37] } & \multirow[t]{2}{*}{ Victoria, Australia (1983-1995) } & \multirow[t]{2}{*}{2012} & \multirow[t]{2}{*}{ LBW $<2500 \mathrm{~g}$} & Presence of LBW in hypospadias: & \\
\hline & & & & RR (95\% Cl): 2.23 (1.88-2.65) & \\
\hline \multirow[t]{3}{*}{ Akre (1999) [48] } & \multirow[t]{3}{*}{ Sweden (1983-1993) } & \multirow[t]{3}{*}{1220} & \multirow[t]{3}{*}{ NA } & $\begin{array}{l}\text { Presence of LBW in hypospadias: } \\
\text { Adjusted OR ( } 95 \% \text { Cl): }\end{array}$ & \multirow{3}{*}{$\begin{array}{c}\text { Maternal age, parity, severe } \\
\text { pre-eclampsia, other congenital } \\
\text { malformations }\end{array}$} \\
\hline & & & & $<1500$ g: 6.02 (2.51-14.41) & \\
\hline & & & & $1500-2500$ g: 2.57 (1.71-3.85) & \\
\hline \multirow[t]{3}{*}{ Weidner (1999) [49] } & Denmark (1983-1992) & 1345 & NA & $\begin{array}{l}\text { Presence of LBW in hypospadias: } \\
\text { Adjusted OR ( } 95 \% \text { Cl): }\end{array}$ & $\begin{array}{l}\text { Sibling with hypospadias, } \\
\text { previous maternal }\end{array}$ \\
\hline & & & & <2500 g: $3.42(2.83-4.13)$ & 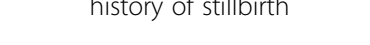 \\
\hline & & & & 2500-2599: $1.76(1.47-2.10)$ & \\
\hline
\end{tabular}


Table 1 Summary of epidemiological studies associating hypospadias with low birth weight (Continued)

\begin{tabular}{|c|c|c|c|c|c|}
\hline \multirow[t]{4}{*}{ Carmichael (2003) [4] } & \multirow[t]{4}{*}{ California, USA (1984-1997) } & \multirow[t]{4}{*}{5838} & \multirow[t]{4}{*}{ NA } & Presence of LBW in hypospadias: & \multirow{4}{*}{$\begin{array}{l}\text { White ethnicity, maternal } \\
\text { education, maternal age, parity }\end{array}$} \\
\hline & & & & Adjusted RR (95\% Cl) & \\
\hline & & & & $\begin{array}{c}<1500 \text { g: } 2.46 \text { (1.65-3.68) to } 57.5 \\
\text { (31.8-104) depending on severity } \\
\text { and other anomalies }\end{array}$ & \\
\hline & & & & $1500-2499$ g: $2.16(1.73-2.69)$ to $18.8(12.4-28.5)$ & \\
\hline \multirow[t]{2}{*}{ Carlson (2009) [58] } & \multirow[t]{2}{*}{ Nova Scotia, Canada (1980-2007) } & \multirow[t]{2}{*}{995} & \multirow[t]{2}{*}{ NA } & Birth weight in different severities of hypospadias: & \multirow[t]{2}{*}{ Maternal age } \\
\hline & & & & Adjusted OR 1.00, 95\% Cl 0.99-1.00 & \\
\hline \multirow[t]{3}{*}{ Ghirri (2009) [59] } & \multirow[t]{3}{*}{ Italy (2001-2004) } & \multirow[t]{3}{*}{234} & \multirow{3}{*}{$\begin{array}{l}\text { SGA: }<10 \text { percentile } \\
\text { for gestational age }\end{array}$} & Prevalence of hypospadias in SGA: & \multirow[t]{3}{*}{ None } \\
\hline & & & & $\begin{array}{l}5.28 \text { per } 1000 \text { live births (compared } \\
\text { to } 2.56 \text { per } 1000 \text { in } A G A \text { ), } p<0.01\end{array}$ & \\
\hline & & & & $\begin{array}{c}\text { Significance only in moderate-severe } \\
\text { hypospadias }\end{array}$ & \\
\hline \multirow[t]{3}{*}{ Nordenvall (2014) [13] } & \multirow[t]{3}{*}{ Sweden (1973-2009) } & \multirow[t]{3}{*}{7974} & \multirow[t]{3}{*}{ SGA: <2 SD below mean } & Presence of SGA in hypospadias: & \multirow{3}{*}{$\begin{array}{c}\text { Parental origin, maternal body } \\
\text { mass index, in vitro fertilization, } \\
\text { twin pregnancy }\end{array}$} \\
\hline & & & & Adjusted OR (95\% Cl): & \\
\hline & & & & $4.15(3.87-4.56)$ & \\
\hline
\end{tabular}


of hypospadias. Interestingly, one study did find a lower risk of hypospadias in twins compared to singletons when adjusted for weight, although this study did not compare weights between discordant twins [49].

Despite the evidence supporting the association between LBW and hypospadias, some debate continues. Determining causality is difficult due to the nature of the available studies. In addition, some studies find either no correlation between hypospadias and birth weight after accounting for confounders [58] or that birth weight was a risk factor only for severe hypospadias [59]. However, the populations in these studies were smaller than those in the studies that found a broader association between LBW and hypospadias.

\section{Possible mechanisms}

Hypospadias is the result of incomplete fusion or failure of fusion of the urethral folds during early fetal development. Two basic phases occur in the development of a male phenotype. The first phase is testicular development, which typically is determined by the presence of the $\mathrm{Y}$ chromosome, specifically the SRY gene, although many other genes also participate in testicular development. The second phase involves androgen effects through production by the testes as well as downstream responses. Defects in either phase may lead to abnormal sexual differentiation [60]. Typically, the external genitalia are undifferentiated until approximately week 8 of gestation, at which time differentiation to male external genitalia begins. During this critical period, human chorionic gonadotropin (HCG) induces masculinization by stimulating the production of testosterone and dihydrotestosterone (DHT) by the interstitial cells of the fetal testes. Fusion of the urethral folds usually is complete by approximately week 16 of gestation; thus, environmental or hormonal disturbances, including any underlying causes of IUGR, must occur before this time to cause hypospadias [61]. Although establishing conclusively that early IUGR is associated with development of hypospadias is difficult, one retrospective cohort study did find a higher rate of hypospadias in infants who were SGA in all three birth measures (i.e., weight, length, and head circumference), compared to those considered appropriate or large for gestational age. The combination of SGA measurements is suggestive of growth restriction early in gestation [51].

Several studies have associated birth weight and hypospadias to disturbances in the fetal-placental-maternal unit. In SGA infants, including those with hypospadias, some researchers have noted an association with maternal hypertension, oligohydramnios, and preterm birth $[62,63]$. Placental and fetal weight tend to be lower in hypospadic infants, independent of gestational age $[47,62,64,65]$, and the severity of hypospadias is increased in SGA infants [63].
Other studies looking more directly at the placenta and fetal growth suggested placental insufficiency as an inciting factor for both LBW and hypospadias. Histopathologic examination of placentas of patients with hypospadias and LBW revealed abnormalities such as low placental weight, evidence of infarction, calcifications, abnormal cord insertion, and other degenerative changes [57,64].

Based on the associations between LBW or IUGR and hypospadias, some researchers have hypothesized that placental insufficiency in the first trimester may cause inadequate HCG delivery to the fetus, with the resultant fetal production of testosterone and DHT being inadequate to induce complete virilization $[51,56,61]$. The timing is critical, as later placental insufficiency might cause IUGR but not hypospadias, as the fusion of the urethral folds is complete by week 16 . This hypothesis has been challenged, as some studies have found no difference in maternal HCG levels before 18 weeks gestation in patients with hypospadias compared to controls [66] and higher than normal second-trimester maternal HCG levels in mothers with placental dysfunction [67]. However, these studies did not necessarily measure maternal HCG levels in the period of time when urethral fusion would be expected to occur. Regardless, normal or high maternal HCG levels do not guarantee that sufficient levels are available to the fetus to produce testosterone and DHT levels adequate for virilization, as the HCG levels seen by the fetus is dependent on an intact placental vessel delivery system.

In patients with IUGR and hypospadias, are the diagnostic evaluation and management of the hypospadias different from those for patients without IUGR?

We did not identify studies that discussed the diagnostic evaluation and management of hypospadias specifically in the setting of IUGR or LBW. Although some genetic syndromes feature both IUGR and hypospadias (e.g., Wolf-Hirschhorn (4p-) syndrome [68] and others), they are rare, and the evidence is insufficient to suggest that the evaluation of hypospadias should differ significantly in IUGR patients compared to normal-weight patients. Evaluation of patients with both IUGR and hypospadias should include a systematic, evidence-based approach, such as the algorithm provided in Figure 1, summarized below.

For infants with hypospadias and evidence of IUGR, assessment should begin with evaluation of an underlying etiology for the growth restriction, including genetic abnormalities or infection [34], if a cause of poor growth was not identified prenatally. Karyotype or chromosomal microarray evaluation would be particularly useful to identify genetic etiologies of severe hypospadias as well as IUGR, as patients with sex chromosome abnormalities, including but not limited to $46 \mathrm{XY} / 45 \mathrm{XO}$ or $46 \mathrm{XX}$ with virilization, can present with some degree of DSD [69]. If 


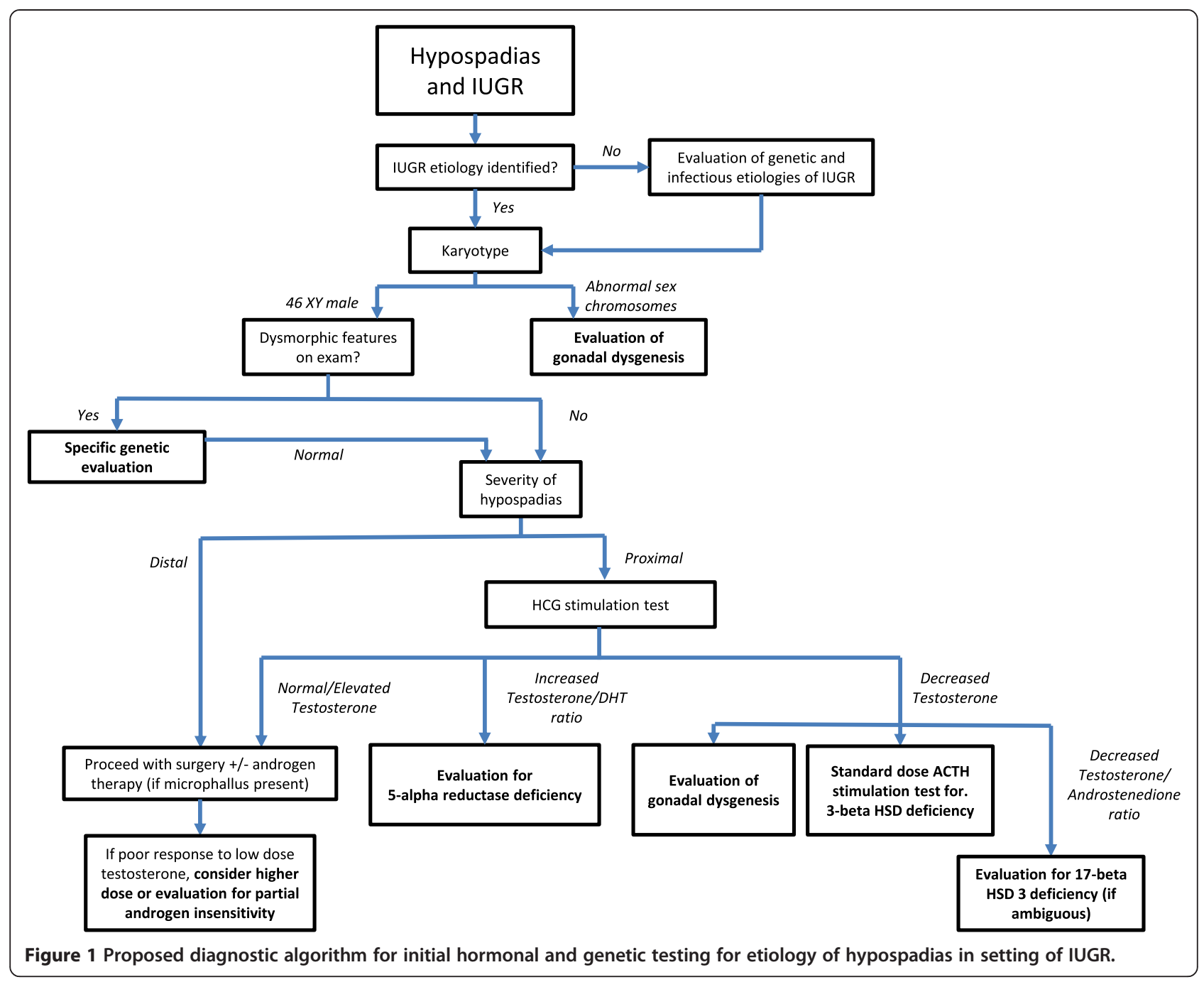

sex chromosome aneuploidy is present, one should consider further evaluation for gonadal dysgenesis.

In the evaluation of hypospadias in infants known to be $46 \mathrm{XY}$, the severity of hypospadias must be considered, as pathology identified is more often in severe cases. The classification of hypospadias usually depends on the location of the urethral opening (Figure 2) [70-73], as well as the presence of other genitourinary anomalies such as cryptorchidism. Some studies have evaluated the hormonal status in patients with hypospadias, with inconsistent protocols and results. However, evaluation of HCGstimulated testosterone and DHT production may be the most useful in diagnosing an endocrine etiology for hypospadias. Patients with hypospadias may have abnormal stimulated production of testosterone, especially if other genitourinary abnormalities are present on exam [74-76]. Increased testosterone-to-DHT ratio suggests 5-alpha reductase deficiency, whereas decreased testosterone production may indicate testicular dysgenesis or defects in steroidogenesis, including 3-beta hydroxysteroid

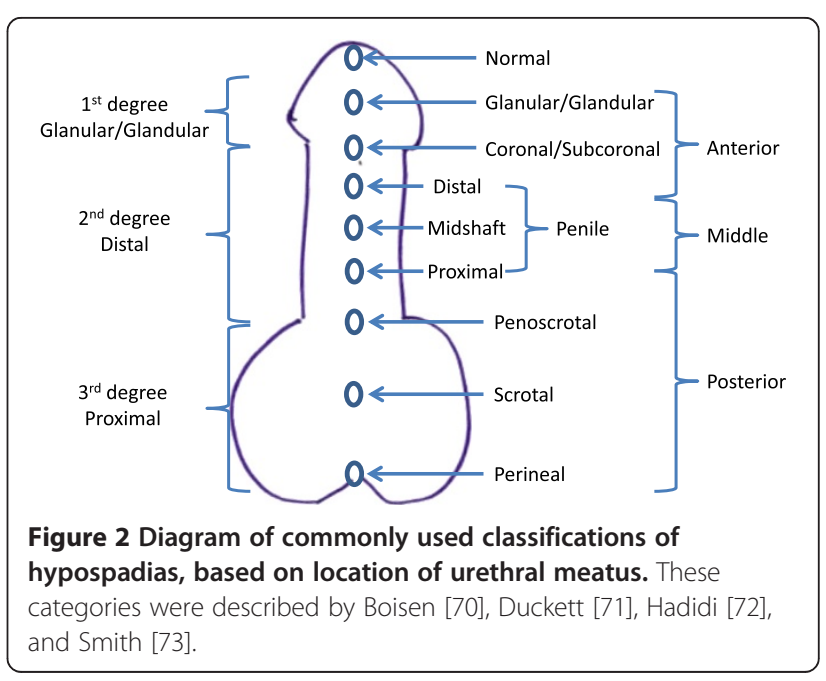


dehydrogenase deficiency or 17-beta hydroxysteroid deficiency. Elevated androgen levels may occur in partial androgen insensitivity. If dysmorphic features or multiple congenital anomalies exist, further genetic evaluation may be indicated for evaluation of known syndromes.

Surgery is the definitive treatment for hypospadias, and preoperative androgen therapy often helps facilitate the repair, particularly in patients with small penile size, although its use remains controversial [77]. Preoperative androgen therapy increases penile length, diameter, or circumference with minimal and transient side effects [78-83]. Intramuscular testosterone is the preferred therapy [77,79-81], although some studies have reported positive outcomes with topical testosterone and DHT $[78,83,84]$. The dosages of intramuscular testosterone varied, but studies using low-dose testosterone enanthate $(2 \mathrm{mg} / \mathrm{kg}$ or $25 \mathrm{mg})$ or equivalent doses of other formulations had beneficial results in penile size similar to those of studies using higher doses. For patients with 5-alpha reductase deficiency or partial androgen insensitivity, a higher dose or multiple courses of testosterone therapy may be needed [85]. DHT, if available, may also be useful in patients with 5-alpha reductase deficiency [86].

\section{Conclusions}

Hypospadias is one of the most common congenital malformations in males, but its etiology remains poorly understood. LBW or growth restriction, which often is associated with hypospadias, is one of the risk factors that researchers have evaluated. The mechanism is unknown, but placental insufficiency as a possible cause of both IUGR/LBW and hypospadias should be studied further. The current evidence is insufficient to recommend that patients with IUGR and hypospadias be assessed and managed differently from patients of normal weight. Further studies are needed to develop a standardized algorithm for diagnostic evaluation and management to minimize cost and patient discomfort and to determine whether hypospadias in the setting of IUGR should be considered a separate DSD entity in the future.

\section{Abbreviations}

IUGR: Intrauterine growth restriction; LBW: Low birth weight; SGA: Small for gestational age; EFW: Estimated fetal weight; HCG: Human chorionic gonadotropin; DHT: Dihydrotestosterone; DSD: Disorders of sex development; OR: Odds ratio; RR: Relative risk; Cl: Confidence interval.

\section{Competing interests}

The authors declare that they have no competing interests.

\section{Authors' contributions}

MJC performed the literature review and drafted the manuscript. CM provided the training necessary for composing an evidence-based review article, critically appraised the paper, and provided key changes to the intellectual content. JD, SG, DR, and BS also critically reviewed the manuscript and made key changes with respect to the design and intellectual content. LK was involved in the initial conception and design of the manuscript as well as critical review and key changes to the intellectual content. All authors read and approved the final manuscript.

\section{Authors' information}

MJC is a third-year clinical Pediatric Endocrinology fellow at Baylor College of Medicine, Texas Children's Hospital.

CM is an Associate Professor in the Department of Pediatrics, Section of Emergency Medicine at Baylor College of Medicine, Texas Children's Hospital. $\mathrm{He}$ is also the director for the Evidence-based Outcomes Center and Center for Clinical Effectiveness at Texas Children's Hospital.

JD is an Associate Professor, Section Chief, and Fellowship Director of Pediatric \& Adolescent Gynecology at Baylor College of Medicine, Texas Children's Hospital.

SG is an Associate Professor in the Department of Pediatrics, Section of Pediatric Diabetes and Endocrinology, at Baylor College of Medicine, Texas Children's Hospital.

DR is a Professor of Urology, Pediatrics, and Obstetrics/Gynecology, and Chief of Pediatric Urology at Baylor College of Medicine, Texas Children's Hospital.

BS is an Assistant Professor of Pediatric Urology at University of Texas Southwestern.

LK is a Professor in the Department of Pediatrics, Section of Pediatric Diabetes and Endocrinology, at Baylor College of Medicine, Texas Children's Hospital.

\section{Acknowledgements}

The authors are very grateful to Dr. B. Lee Ligon (Department of Pediatrics and Center for Research, Innovation, and Scholarship at Baylor College of Medicine) for her editorial contributions; Abiola Odejimi (medical student at Baylor College of Medicine) and Thomas Burke (Evidence-based Outcomes Center at Texas Children's Hospital), who assisted with the initial literature search, and Dr. Jake Kushner, Chief of Pediatric Diabetes and Endocrinology at Baylor College of Medicine/Texas Children's Hospital for his support.

\section{Author details}

'Section of Pediatric Diabetes and Endocrinology, Department of Pediatrics, Baylor College of Medicine, Texas Children's Hospital, Houston, TX 77030, USA. ${ }^{2}$ Evidence-Based Outcomes Center and Center for Clinical Effectiveness, Baylor College of Medicine, Texas Children's Hospital, Houston, TX 77030, USA. ${ }^{3}$ Division of Pediatric and Adolescent Gynecology, Department of Obstetrics and Gynecology, Baylor College of Medicine, Texas Children's Hospital, Houston, TX 77030, USA. ${ }^{4}$ Division of Pediatric Urology, Department of Surgery, Baylor College of Medicine, Texas Children's Hospital, Houston, TX 77030, USA.

${ }^{5}$ Department of Urology, University of Texas Southwestern, Dallas, TX 75207, USA.

Received: 30 May 2014 Accepted: 4 September 2014

Published: 15 October 2014

\section{References}

1. Canon S, Mosley B, Chipollini J, Purifoy JA, Hobbs C: Epidemiological assessment of hypospadias by degree of severity. J Urol 2012, 188:2362-2366.

2. Sweet RA, Schrott HG, Kurland R, Culp OS: Study of the incidence of hypospadias in Rochester, Minnesota, 1940-1970, and a case-control comparison of possible etiologic factors. Mayo Clin Proc 1974, 49:52-58.

3. Gallentine ML, Morey AF, Thompson IM Jr: Hypospadias: a contemporary epidemiologic assessment. Urology 2001, 57:788-790.

4. Carmichael SL, Shaw GM, Nelson V, Selvin S, Torfs CP, Curry CJ: Hypospadias in California: trends and descriptive epidemiology. Epidemiology 2003, 14:701-706.

5. Fisch $\mathrm{H}$, Hyun $\mathrm{G}$, Hensle TW: Rising hypospadias rates: disproving a myth. J Pediatr Urol 2010, 6:37-39.

6. Fisch $\mathrm{H}$, Lambert SM, Hensle TW, Hyun G: Hypospadias rates in new york state are not increasing. J Urol 2009, 181:2291-2294.

7. Porter MP, Faizan MK, Grady RW, Mueller BA: Hypospadias in Washington State: maternal risk factors and prevalence trends. Pediatrics 2005, 115:e495-e499.

8. Paulozzi LJ, Erickson JD, Jackson RJ: Hypospadias trends in two US surveillance systems. Pediatrics 1997, 100:831-834.

9. Nelson CP, Park JM, Wan J, Bloom DA, Dunn RL, Wei JT: The increasing incidence of congenital penile anomalies in the United States. J Urol 2005, 174:1573-1576. 
10. Toppari J, Kaleva M, Virtanen HE: Trends in the incidence of cryptorchidism and hypospadias, and methodological limitations of registry-based data. Hum Reprod Update 2001, 7:282-286.

11. Nassar N, Bower C, Barker A: Increasing prevalence of hypospadias in Western Australia, 1980-2000. Arch Dis Child 2007, 92:580-584

12. Lund L, Engebjerg MC, Pedersen L, Ehrenstein V, Norgaard M, Sorensen HT: Prevalence of hypospadias in Danish boys: a longitudinal study, 1977-2005. Eur Urol 2009, 55:1022-1026.

13. Nordenvall AS, Frisen L, Nordenstrom A, Lichtenstein P, Nordenskjold A: Population based nationwide study of hypospadias in Sweden, 1973 to 2009: incidence and risk factors. J Urol 2014, 191:783-789.

14. Silver Rl, Russell DW: 5alpha-reductase type 2 mutations are present in some boys with isolated hypospadias. J Urol 1999, 162:1142-1145.

15. Batch JA, Evans BA, Hughes IA, Patterson MN: Mutations of the androgen receptor gene identified in perineal hypospadias. J Med Genet 1993, 30:198-201.

16. Smith DW, Lemli L, Opitz JM: A newly recognized syndrome of multiple congenital anomalies. J Pediatr 1964, 64:210-217.

17. Shih EM, Graham JM Jr: Review of genetic and environmental factors leading to hypospadias. Eur J Med Genet 2014, 57:453-463.

18. Kohler B, Lin L, Mazen I, Cetindag C, Biebermann H, Akkurt I, Rossi R, Hiort O, Gruters A, Achermann JC: The spectrum of phenotypes associated with mutations in steroidogenic factor 1 (SF-1, NR5A1, Ad4BP) includes severe penoscrotal hypospadias in $46, \mathrm{XY}$ males without adrenal insufficiency. Eur J Endocrinol 2009, 161:237-242.

19. Ogata T, Sano S, Nagata E, Kato F, Fukami M: MAMLD1 and 46, XY disorders of sex development. Semin Reprod Med 2012, 30:410-416.

20. Pelletier J, Bruening W, Li FP, Haber DA, Glaser T, Housman DE: WT1 mutations contribute to abnormal genital system development and hereditary Wilms' tumour. Nature 1991, 353:431-434.

21. Kalfa N, Philibert P, Sultan C: Is hypospadias a genetic, endocrine or environmental disease, or still an unexplained malformation? Int J Androl 2009, 32:187-197.

22. Rocheleau CM, Romitti PA, Dennis LK: Pesticides and hypospadias: a meta-analysis. J Pediatr Urol 2009, 5:17-24.

23. van der Zanden LF, Galesloot TE, Feitz WF, Brouwers MM, Shi M, Knoers NV, Franke B, Roeleveld N, van Rooij IA: Exploration of gene-environment interactions, maternal effects and parent of origin effects in the etiology of hypospadias. J Urol 2012, 188:2354-2360.

24. van der Zanden LF, van Rooij IA, Feitz WF, Franke B, Knoers NV, Roeleveld N: Aetiology of hypospadias: a systematic review of genes and environment. Hum Reprod Update 2012, 18:260-283.

25. Wang MH, Baskin LS: Endocrine disruptors, genital development, and hypospadias. J Androl 2008, 29:499-505.

26. Organization WH: ICD-10 International Statistical Classification of Diseases and Related Health Problems. 4th edition. Geneva: World Health Organization; 2011

27. Laron Z, Mimouni F: Confusion around the definition of small for gestational age (SGA). Pediatr Endocrinol Rev 2005, 2:364-365

28. Lee PA, Chernausek SD, Hokken-Koelega AC, Czernichow P, International Small for Gestational Age Advisory Board: International Small for Gestational Age Advisory Board consensus development conference statement: management of short children born small for gestational age, April 24-October 1, 2001. Pediatrics 2003, 111:1253-1261.

29. Committee on Practice Bulletins-Gynecology, American College of Obstetricians and Gynecologists, Washington D. C. U. S. A: Intrauterine growth restriction. Clinical management guidelines for obstetrician-gynecologists. American College of Obstetricians and Gynecologists. Int J Gynaecol Obstet 2001, 72:85-96.

30. Lausman A, Kingdom J, Maternal Fetal Medicine C, Gagnon R, Basso M, Bos H, Crane J, Davies G, Delisle MF, Hudon L, Menticoglou S, Mundle W, Ouellet A, Pressey T, Pylypjuk C, Roggensack A, Sanderson F: Intrauterine growth restriction: screening, diagnosis, and management. J Obstet Gynaecol Can 2013, 35:741-757.

31. Royal College of Obstetricians and Gynaecologists: The investigation and management of the small-for gestational age fetus. In Green-top Guideline No 31. 2nd edition. London: Royal College of Obstetricians and Gynaecologists; 2013.

32. Unterscheider J, Daly S, Geary MP, Kennelly MM, McAuliffe FM, O'Donoghue K, Hunter A, Morrison JJ, Burke G, Dicker P, Tully EC, Malone FD: Optimizing the definition of intrauterine growth restriction: the multicenter prospective PORTO Study. Am J Obstet Gynecol 2013, 208:290. e291-296.
33. Unterscheider J, Daly S, Geary MP, Kennelly MM, McAuliffe FM, O'Donoghue K, Hunter A, Morrison JJ, Burke G, Dicker P, Tully EC, Malone FD: Definition and management of fetal growth restriction: a survey of contemporary attitudes. Eur J Obstet Gynecol Reprod Biol 2014, 174:41-45.

34. Lin CC, Santolaya-Forgas J: Current concepts of fetal growth restriction: part I. Causes, classification, and pathophysiology. Obstet Gynecol 1998, 92:1044-1055.

35. Khoury MJ, Erickson JD, Cordero JF, MCCarthy BJ: Congenital malformations and intrauterine growth retardation: a population study. Pediatrics 1988, 82:83-90.

36. Mili F, Edmonds LD, Khoury MJ, McClearn AB: Prevalence of birth defects among low-birth-weight infants. A population study. Am J Dis Child 1991, 145:1313-1318.

37. Riley MM, Halliday JL, Lumley JM: Congenital malformations in Victoria, Australia, 1983-95: an overview of infant characteristics. J Paediatr Child Health 1998, 34:233-240.

38. Chambers CD, Castilla EE, Orioli I, Jones KL: Intrauterine growth restriction in like-sex twins discordant for structural defects. Birth Defects Res A Clin Mol Teratol 2006, 76:246-248

39. Marengo L, Farag NH, Canfield M: Body mass index and birth defects: Texas, 2005-2008. Matern Child Health J 2013, 17:1898-1907.

40. Aucott SW, Donohue PK, Northington FJ: Increased morbidity in severe early intrauterine growth restriction. J Perinatol 2004, 24:435-440.

41. van Wassenaer A: Neurodevelopmental consequences of being born SGA. Pediatr Endocrinol Rev 2005, 2:372-377.

42. Chernausek SD: Update: consequences of abnormal fetal growth. J Clin Endocrinol Metab 2012, 97:689-695.

43. Chen YC, Woolley PV Jr: Genetic studies on hypospadias in males. J Med Genet 1971, 8:153-159.

44. Kallen B, Winberg J: An epidemiological study of hypospadias in Sweden. Acta Paediatr Scand Suppl 1982, 293:1-21.

45. Calzolari E, Contiero MR, Roncarati E, Mattiuz PL, Volpato S: Aetiological factors in hypospadias. J Med Genet 1986, 23:333-337.

46. Kallen B, Bertollini R, Castilla E, Czeizel A, Knudsen LB, Martinez-Frias ML, Mastroiacovo P, Mutchinick O: A joint international study on the epidemiology of hypospadias. Acta Paediatr Scand Supp/ 1986, 324:1-52.

47. Stoll C, Alembik Y, Roth MP, Dott B: Genetic and environmental factors in hypospadias. J Med Genet 1990, 27:559-563.

48. Akre O, Lipworth L, Cnattingius S, Sparen P, Ekbom A: Risk factor patterns for cryptorchidism and hypospadias. Epidemiology 1999, 10:364-369.

49. Weidner IS, Moller H, Jensen TK, Skakkebaek NE: Risk factors for cryptorchidism and hypospadias. J Urol 1999, 161:1606-1609.

50. Hsieh MH, Alonzo DG, Gonzales ET, Jones EA, Cisek $\sqcup$, Roth DR: Ex-premature infant boys with hypospadias are similar in size to age-matched, ex-premature infant boys without hypospadias. J Pediatr Urol 2011, 7:543-547.

51. Hussain N, Chaghtai A, Herndon CD, Herson VC, Rosenkrantz TS, McKenna PH: Hypospadias and early gestation growth restriction in infants. Pediatrics 2002, 109:473-478.

52. Cox K, Bryce J, Jiang J, Rodie M, Sinnott R, Alkhawari M, Arlt W, Audi L Balsamo A, Bertelloni S, Cools M, Darendeliler F, Drop S, Ellaithi M, Guran T, Hiort O, Holterhus PM, Hughes I, Krone N, Lisa L, Morel Y, Soder O, Wieacker P, Ahmed SF: Novel associations in disorders of sex development: findings from the I-DSD Registry. J Clin Endocrinol Metab 2014, 99:E348-355.

53. Sekaran P, OToole S, Flett M, Cascio S: Increased occurrence of disorders of sex development, prematurity and intrauterine growth restriction in children with proximal hypospadias associated with undescended testes. J Urol 2013, 189:1892-1896.

54. Francois I, van Helvoirt M, de Zegher F: Male pseudohermaphroditism related to complications at conception, in early pregnancy or in prenatal growth. Horm Res 1999, 51:91-95.

55. de Andrade Machado Neto F, Moreno Morcillo A, Trevas Maciel-Guerra A, Guerra-Junior G: Idiopathic male pseudohermaphroditism is associated with prenatal growth retardation. Eur J Pediatr 2005, 164:287-291.

56. Fredell L, Lichtenstein P, Pedersen NL, Svensson J, Nordenskjold A Hypospadias is related to birth weight in discordant monozygotic twins. J Urol 1998, 160:2197-2199.

57. Yinon Y, Kingdom JC, Proctor LK, Kelly EN, Salle JL, Wherrett D, Keating $S$, Nevo O, Chitayat D: Hypospadias in males with intrauterine growth restriction due to placental insufficiency: the placental role in the embryogenesis of male external genitalia. Am J Med Genet A 2010, 152A:75-83 
58. Carlson WH, Kisely SR, MacLellan DL: Maternal and fetal risk factors associated with severity of hypospadias: a comparison of mild and severe cases. J Pediatr Urol 2009, 5:283-286

59. Ghirri P, Scaramuzzo RT, Bertelloni S, Pardi D, Celandroni A, Cocchi G, Danieli R, De Santis L, Di Stefano MC, Gerola O, Giuffre M, Gragnani GS, Magnani C, Meossi C, Merusi I, Sabatino G, Tumini S, Corsello G, Boldrini A: Prevalence of hypospadias in Italy according to severity, gestational age and birthweight: an epidemiological study. Ital J Pediatr 2009, 35:18.

60. Kalfa N, Sultan C, Baskin LS: Hypospadias: etiology and current research. Urol Clin North Am 2010, 37:159-166.

61. Baskin LS: Hypospadias and urethral development. J Urol 2000, 163:951-956

62. Chong JH, Wee CK, Ho SK, Chan DK: Factors associated with hypospadias in Asian newborn babies. J Perinat Med 2006, 34:497-500.

63. Huisma F, Thomas M, Armstrong L: Severe hypospadias and its association with maternal-placental factors. Am J Med Genet A 2013, 161:2183-2187.

64. Fujimoto T, Suwa T, Kabe K, Adachi T, Nakabayashi M, Amamiya T: Placental insufficiency in early gestation is associated with hypospadias. $J$ Pediatr Surg 2008, 43:358-361.

65. Gatti JM, Kirsch AJ, Troyer WA, Perez-Brayfield MR, Smith EA, Scherz HC: Increased incidence of hypospadias in small-for-gestational age infants in a neonatal intensive-care unit. BJU Int 2001, 87:548-550

66. Kiely EA, Chapman RS, Bajoria SK, Hollyer JS, Hurley R: Maternal serum human chorionic gonadotrophin during early pregnancy resulting in boys with hypospadias or cryptorchidism. Br J Urol 1995, 76:389-392.

67. Morssink LP, de Wolf BT, Kornman LH, Beekhuis JR, van der Hall TP, Mantingh $A$ : The relation between serum markers in the second trimester and placental pathology. A study on extremely small for gestational age fetuses. Br J Obstet Gynaecol 1996, 103:779-783.

68. Battaglia A, Filippi T, Carey JC: Update on the clinical features and natura history of Wolf-Hirschhorn (4p-) syndrome: experience with 87 patients and recommendations for routine health supervision. Am J Med Genet $C$ Semin Med Genet 2008, 148C:246-251.

69. Douglas GV, Bacino CA, Weimin B, Breman AM, Cheung SW, Lalani SR, Shaw C, Smith JL, Stankiewicz P, Sutton VR, Patel A: Utilization and findings of Chromosomal Microarray Analysis (CMA) in patients with ambiguous genitalia [Abstract]. In American College of Medical Genetics and Genomics Annual Clinical Genetics Meeting. Phoenix, AZ: 2013.

70. Boisen KA, Chellakooty M, Schmidt IM, Kai CM, Damgaard IN, Suomi AM, Toppari J, Skakkebaek NE, Main KM: Hypospadias in a cohort of 1072 Danish newborn boys: prevalence and relationship to placental weight, anthropometrical measurements at birth, and reproductive hormone levels at three months of age. J Clin Endocrinol Metab 2005, 90:4041-4046.

71. Duckett JW: Hypospadias. In Adult and Pediatric Urology. 3rd edition. Edited by Gillenwater JY, Grayhack JT, Howard SS, Duckett JW. St Louis: Mosby; 1996:2550-2565

72. Hadidi A: Classification of hypospadias. In Hypospadias Surgery. Edited by Hadidi A, Azmy A. Berlin Heidelberg: Springer; 2004:79-82.

73. Smith C: Surgical procedures for correction of hypospadias. J Urol 1938, 40:239-245

74. Feyaerts A, Forest MG, Morel Y, Mure PY, Morel-Journel N, Mallet D, Nicolino M, Chatelain P, David M, Mouriquand P: Endocrine screening in 32 consecutive patients with hypospadias. J Urol 2002, 168:720-725. discussion 725.

75. Ratan SK, Aggarwal S, Mishra TK, Saxena A, Yadav S, Pandey R, Sharma A, Dhanwal D: Children with isolated hypospadias have different hormonal profile compared to those with associated anomalies. J Pediatr Endocrinol Metab 2012, 25:111-119.

76. Rey RA, Codner E, Iniguez G, Bedecarras P, Trigo R, Okuma C, Gottlieb S, Bergada I, Campo SM, Cassorla FG: Low risk of impaired testicular Sertoli and Leydig cell functions in boys with isolated hypospadias. J Clin Endocrinol Metab 2005, 90:6035-6040.

77. Gorduza DB, Gay CL, de Mattos ESE, Demede D, Hameury F, Berthiller J, Mure PY, Mouriquand PD: Does androgen stimulation prior to hypospadias surgery increase the rate of healing complications? - A preliminary report. J Pediatr Urol 2011, 7:158-161.

78. Chalapathi G, Rao KL Chowdhary SK, Narasimhan KL, Samujh R, Mahajan JK. Testosterone therapy in microphallic hypospadias: topical or parenteral? J Pediatr Surg 2003, 38:221-223.

79. Ishii T, Hayashi M, Suwanai A, Amano N, Hasegawa T: The effect of intramuscular testosterone enanthate treatment on stretched penile length in prepubertal boys with hypospadias. Urology 2010, 76:97-100
80. Ahmad R, Chana RS, Ali SM, Khan S: Role of parenteral testosterone in hypospadias: A study from a teaching hospital in India. Urol Ann 2011 3:138-140

81. Koff SA, Jayanthi VR: Preoperative treatment with human chorionic gonadotropin in infancy decreases the severity of proximal hypospadias and chordee. J Urol 1999, 162:1435-1439.

82. Luo CC, Lin JN, Chiu CH, Lo FS: Use of parenteral testosterone prior to hypospadias surgery. Pediatr Surg Int 2003, 19:82-84.

83. Nerli RB, Koura A, Prabha V, Reddy M: Comparison of topical versus parenteral testosterone in children with microphallic hypospadias. Pediatr Surg Int 2009, 25:57-59.

84. Bastos AN, Oliveira LR, Ferrarez CE, de Figueiredo AA, Favorito LA, Bastos Netto JM: Structural study of prepuce in hypospadias-does topical treatment with testosterone produce alterations in prepuce vascularization? J Urol 2011, 185:2474-2478.

85. Price P, Wass JA, Griffin JE, Leshin M, Savage MO, Large DM, Bu'Lock DE, Anderson DC, Wilson JD, Besser GM: High dose androgen therapy in male pseudohermaphroditism due to 5 alpha-reductase deficiency and disorders of the androgen receptor. J Clin Invest 1984, 74:1496-1508.

86. Imperato-McGinley J: 5 alpha-reductase-2 deficiency. Curr Ther Endocrinol Metab 1997, 6:384-387.

doi:10.1186/1687-9856-2014-20

Cite this article as: Chen et al:: Intrauterine growth restriction and hypospadias: is there a connection?. International Journal of Pediatric Endocrinology 2014 2014:20

\section{Submit your next manuscript to BioMed Central and take full advantage of:}

- Convenient online submission

- Thorough peer review

- No space constraints or color figure charges

- Immediate publication on acceptance

- Inclusion in PubMed, CAS, Scopus and Google Scholar

- Research which is freely available for redistribution 